Global Journal of Molecular Biology
(ISSN:2637-5141)

\title{
The role of Zi2 during neural tube and neural crest development
}

\section{Gerald Muca*}

Department of Morfofunctional Modules, Faculty of Veterinary Medicine, Agricultural University of Tirana, Koder Kamez, 2021 Tirana-Albania

\section{ABSTRACT}

The transcription factor Zic2 is member of Zic family, at early stages it has been involved in several processes during embryonic development and later on in morphogenesis and organogenesis. An important role has been attributed to Zic2 during the development of the neural system. It has been involved in neural tube and neural crest formation. Both process structures will form the central and peripheral neural system. Mutation of Zic2 provokes holoprosencephaly in humans and in mouse also spina bifida. To date, there is not well elaborated the specific mechanisms under which Zic2 affect neural tube formation and the differences may exist between mouse and human phenotype. Almost the same ambiguity is for the specific role of Zic2 during neural crest development. Here is given are resumed latest studies and are given new insight about the role of Zic2 in these two processes and its new target genes.

\section{Keywords:}

Zic2; neural tube; neural crest; cell proliferation; development
*Correspondence to Author:

Gerald Muca

Department of Morfofunctional Modules, Faculty of Veterinary Medicine, Agricultural University of Tirana Koder Kamez, 2021 Tirana-Albania

How to cite this article:

Gerald Muca.The role of $\mathrm{Zi} 2$ during neural tube and neural crest development. Global Journal of Molecular Biology, 2019, 2:6

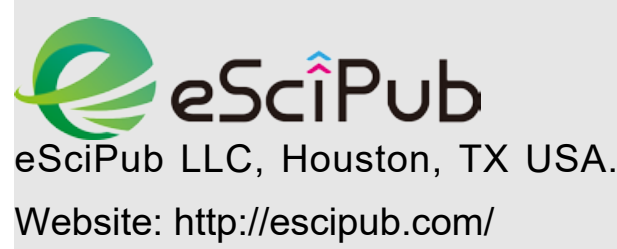




\section{Overview of Zic gene family and Zic2.}

Zic is family of genes is composed of five members in Xenopus, chicken, and mammals, whereas in zebrafish are seven members (Houtmeyers et al., 2013). All Zic family members are vertebrate homologues of the Drosophila Odd-paired (opa) gene (Aruga et al., 1996; Furushima et al., 2000). For the first time this family of genes was identified as a group of genes encoding zinc finger proteins expressed in adult cerebellum.

Zic2 gene is composed of a three exons structure and it is located in human on chromosome 13, in the mouse on chromosome
14 (Grinberg and Millen, 2005), in chicken on chromosome 4 and zebrafish on chromosome 2 (Houtmeyers et al., 2013; McMahon and Merzdorf, 2010). The production of Zic2 gene is a protein of five Cys2His2 zinc-finger domains composed by 533 amino acids (Ali et al., 2012; Aruga et al., 1996), (figure 1). Zic2 is expressed early during development starting from early gastrulation, in the node and later on the dorsal part of the neural tube and paraxial mesoderm. During the organogenesis it is expressed in the brain, spinal cord, visual system and distal part of the limb. (Elms et al., 2004; Nagai et al., 1997).

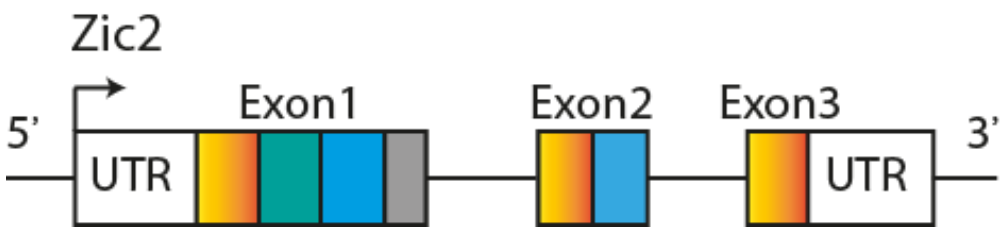

Figure 1. Gene structure of Zic2. White boxes represent untranslated region. Orange degraded boxes represent 5 '-> 3 'coging region. Filled coloured boxes represent zinc finger domains.

\section{The role of Zic2 during neural tube formation.}

Neural tube if formed during neurulation process. The neurulation begins when the neural plate starts bending and it terminates with the fusion of the neural fold where the neural tube forms. The bending process is leaded by two principal hinge point; medial hinge point (MHP) and dorsolateral hinge point (DLHP) (Copp et al., 2003). This process if followed by neural tube dorosventral patterning where cells inside the tube differentiate in specific neural subtypes cells which follow a strict pattern along the anteroposterior and dorsoventral axis (Briscoe et al., 2000; Lee et al., 1998). In some cases, the formation of the neural tube does not develop properly as a consequence the neural tube does not close, that lead to pathologies known as neural tube defects (NTDs). They are frequent congenital malformation in vertebrates. These defects are distributed on the anterior or posterior part of the neural tube. Depending on the location and severity, they take specific names. The more communes are holoprosencephaly (HPE) and spina bifida (Copp and Greene, 2013; Zohn and Sarkar, 2008). The frequency and severity of these pathologies have attracted the focus of developmental biologists and clinicians on unveiling the pathological mechanisms and preventing.

One of the genes associated with NTDs is Zic2. In humans mutation of Zic2 provokes HPE (Brown et al., 1998), whereas in mouse except of HPE it provokes spina bifida (Nagai et al., 2000). To date, there are no clear mechanisms that explanation how the lack of Zic2 leads to these NTDs. The main questions that are not well elaborated are; Is Zic2 involved in cell differentiation or cell proliferation during neural tube development?; Is Zic2 involved in neurulation through bending process or dorsovental cell pattering, or both of them?; Which is the difference regarding NTDs between mouse and human? 
The role of Zic2 in cell differentiation and proliferation during neural tube development.

During later stages of embryonic development the function of Zic2, especially in post mitotic cells in the spinal cord and visual system is well established (Escalante et al., 2013; Herrera et al., 2003). However, the function at early stages of neural development where cells are still in a progenitor stage is ambiguous. It is not clear how Zic2 participates in these cells differentiation or proliferation.

In Xenopus, Zic2 overexpression induced neurogenesis but prohibited cells to differentiate in mature neurons (Brewster et al., 1998). In mouse, during cerebellum formation, it was seen that Zic2 promote granular progenitor cells and at the same time help their survivance (Aruga et al., 2002). In general the results obtained until now conclude that Zic2 is expressed from neural progenitors that are not specified in any neural cell type. This is sustained from results in other cell population. It has been demonstrated that Zic2 is expressed from paraxial mesoderm progenitor cells (Inoue et al., 2007). Similar to somite cells is the case of cancer cells where was seen that Zic2 is expressed from cancer cells (Lu et al., 2017), which do not use to have a clear differentiation.

During the neural tube formation, the apical part is a pool of neural crest and neural cell progenitors (Helms and Johnson, 2003; Kalcheim, 2018). The expression of Zic2 on the dorsal part of the neural tube (Nagai et al., 1997), from neural crest cells (Elms et al., 2003) and at the same time from neural progenitors (Escalante et al., 2013) lead to thinking that Zic2 it could affect the cell proliferation of each population. In a Zic2 full mutat (kumba:ku) and Zic2 hypomorphic $(\mathrm{kd})$ mutant mouse was seen a reduction in neural crest production and a retardation in the roof plate formation. These changes were produced without affecting cell proliferation (Ph3) and cell death (Elms et al., 2003; Nagai et al., 2000).

If there is retardation in one both of the cell population which populate apical part of the neural tube during, we hypothesise there should be a differences in cell cycle or proliferation in one of these cell populations. More plausible is that neural progenitors proliferate more and compensate the reduction in proliferation of neural crest progenitors. This in global view could not give changes in cell proliferation if we do not differentiate the proliferation rate of each group of cells. This is why we think is necessary a detailed study of the cell cycle. With Ph3 we get a snapshot of cells in G2 and M phase but we cannot see how are proliferating different group of cells. In the study of (Nagai et al., 2000) was mentioned that there is no difference in BrdU expression. However, is necessary a detailed study with each cell population of the dorsal part of the neural tube. Double staining for BrdU with markers as it is Hairy 1 for roof plate cells (Nitzan et al., 2016) and Foxd3 for neural crest cell (Thomas and Erickson, 2009) will clarify what is the proliferation rate of these group of cells.

Mechanisms related to Zic2 during the development of the neural tube.

From the two hinging point MHP and DLHP involved in neurulation, the DLHP has been demonstrated to be crucial for closing and sealing of the neural tube (Copp et al., 2003; Ybot-Gonzalez et al., 2002). It is DLHP where Zic2 has been involved; it affects Bmp2 antagonists; neuralin and noggin. In Zic2ku/ku mutant embryos the noggin and neuralin expression were reduced (Ybot-Gonzalez et al., 2007), Figure 2. However, remain to be explored which are the relation of Zic2 with other members of Bpm family.

To a proper DLHP formation are required cytoskeletal elements including actin-myosin network. These cytoskeletal elements are important for neural fold junction and consequently the neural tube closure. In zebrafish has been fund that Zic2a controls Factin and myosin-II distribution during development of the cranial part of the neural tube (Nyholm et al., 2009). Similar results have been found in Zic2 Ku/Ku mutant in the caudal part 
of the neural tube where was seen a reduction of $\mathrm{F}$-actin expression in a region which correspond with spina bifida (Galea et al., 2017), Figure 2. These results give the bending impairment mechanism, which partially explains NTDs. Other mechanisms should be involved that will completely explain NDTs encountered in Zic2 mutant mouse.

Dorsoventral patterning of neural tube is a mechanisms that when also goes wrong can leads to NTDs (Melloy et al., 1998). There are strong indications for an involvement of Zic2 in neural tube dorsoventral patterning. First, Zic2 in cooperation with Zic1 has been involved in cerebellum patterning (Aruga et al., 2002). In zebrafish was also seen that Zic2a and Zic2b participate in forebrain patterning (TeSlaa et al., 2013). Second, indication for involvement of Zic2 dorsoventral patterning is the expression pattern. Zic2 is expressed exclusively from the node at the middle line above neural plate (Elms et al., 2004), and in the dorsal part of the neural tube (Nagai et al., 1997), which will be signalling centres that will constitute neural tube dorsoventral patterning.

In mouse Zic2 ${ }^{\mathrm{Ku} / \mathrm{Ku}}$ was seen defect coming the ventral part of neural tube, specifically from Nodal signalling, which effect prechordal plate formation which is a structure responsible for forebrain formation (Warr et al., 2008). It was seen that Zic2 actuates downstream Nodal signalling. ZIC2 forms a complex with SMAD proteins, then this complex recruits FoxA2, another transcription factors to finally transduce Nodal signalling for a proper prechordal plate development (Houtmeyers et al., 2016), Figure 2.

Regarding the mechanism, it was also discovered that Zic2 controls Tgif1 gene expression (Ishiguro et al., 2018). Tgif1 and his paralogous genes, Tgif2 are inhibitory factors related to holoprosencephaly in humans and mouse (Gripp et al., 2000; Taniguchi et al., 2012). It is was known that Tgifs represses Nodal signalling through inhibiting Smad2 and Smad4 transcription (Wotton et al., 1999).
However, lately was discovered that Tigf1 operates also independently of Nodal signalling. It was seen that Tgif1 controls Gli3 expression which is an effector of Shh signalling (Taniguchi et al., 2017). ZIC2 has been seen to interact with GLI proteins and it can binds to Gli DNA binding site (Koyabu et al., 2001). These results demonstrate an indirect relation between Zic2 and Shh signalling through Tgif1. The indirect relation is reinforced from other results where in mammals is known that ZIC2 does not directly interact with Shh signalling (Warr et al., 2008) and Shh levels does not change in Zic2 ${ }^{\mathrm{kd} / \mathrm{kd}}$ and Zic2 ${ }^{\mathrm{Ku} / \mathrm{Ku}}$ mutant mice (Elms et al., 2003; Nagai et al., 2000). Zic2 has also an opposing expression and does not phenocopy the holoprosencephaly caused by Shh (Chiang et al., 1996; Nagai et al., 2000). However, in Xenpus and zebrafish it was discovered that Zic2a directly regulate the levels of Shh (Sanek and Grinblat, 2008), Figure 2. Further studies are necessary to clarify is Zic2 and Shh signalling regulation mechanisms is conserved in all vertebrates.

Regarding to the dorsal part of the neural tube another path where Zic2 is demonstrated to be involved is Retinoid signalling. This signalling path has been involved in dorosventral patterning of the neural tube (Niederreither et al., 2000; Wilson et al., 2004). It has also been involved in several NTDs on the anterior and posterior part of the neural tube, including anencephaly, holoprosencephaly and spina bifida (Alles and Sulik, 1990; Cohen and Shiota, 2002; Maden, 2006). In mouse it seems that Zic2 also use Tgif1 as an effector gene to control Retinoic acid levels where was seen that Tgif1 inhibit Retinoid signalling (Bartholin et al., 2006). The mechanisms of Zic2 and Tgif1 could explain closure defects in the anterior part of the neural tube where Tgif1 has been associated with holoprosencephaly. However, remains to be seen if Zic2 and Retinoid signalling are related with NTDs of the posterior neural tube where both have been associated with spina bifida. In zebrafish Zic2a and Zic2b control Retinoic acid 
levels in hindbrain region (Drummond et al., 2013). At the same time Retinoid signalling control Zic2 expression levels in Xenopus (Franco et al., 1999), where it activates Erf and Etv3 repressor factors (Janesick et al., 2013), Figure 2. These results demonstrate to the existence of a feedback negative loop between Zic2 and Retinoid acid, which control the expression of each other. Remains to explore if this mechanism apart of Xenopus it is also conserved in other species. All these results indicate for the involvement of Zic2 in dorsoventral patterning of the ventral part of the neural tube. In Zic2kd/kd mutant was also observed retardation in cell differentiation which is manifested with a lag in the expression of Wnt3a, a marker of roof plate cells (Nagai et al., 2000). This is an evidence that Zic2 apart of the ventral neural tube patterning affects also the patterning on the dorsal part. Further work is necessary to explain better the other mechanisms by which Zic2 provoke NTDs in the posterior part of the neural tube.
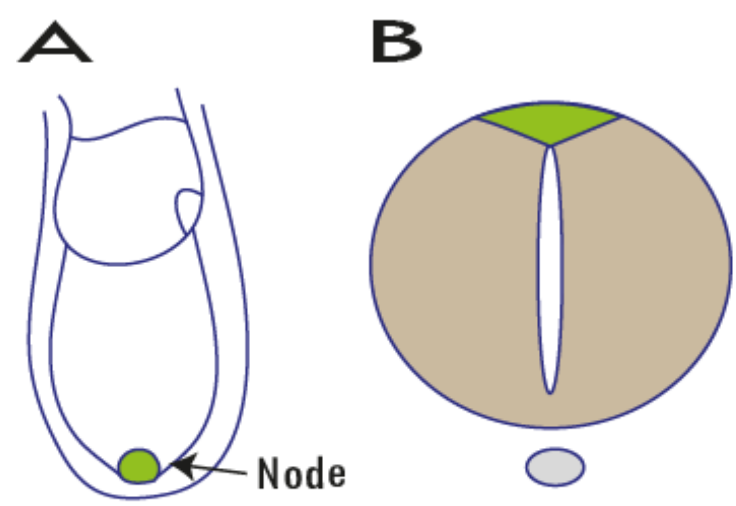

Zic2 expression

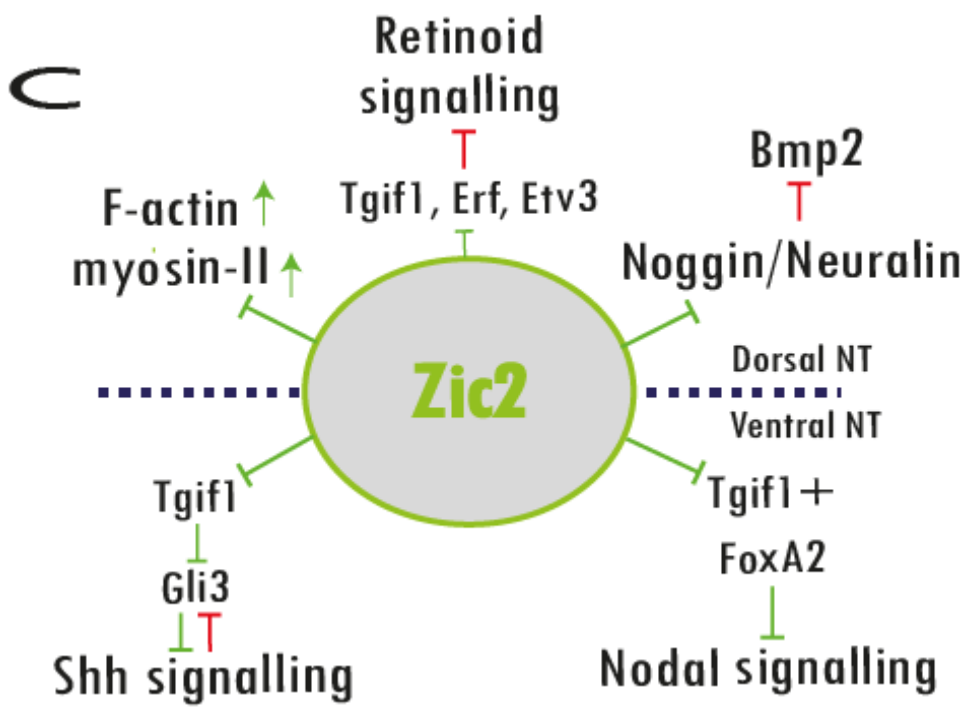

Figure 2. A-Zic2 expression in the node during gastrulation, B-Zic2 expression in the apical part of the neural tube. B-Mechanisms guided by Zic2 during neural tube dorsoventral patterning. Dorsally Zic2 induces expression of Noggin/Neuralin which downregulate Bmp2, it also directly controls F-actin, myosin-II expression and Retinoid signalling through Tgif1, Erf and Etv3.

In humans, Zic2 mutation provoke a specific NTD on the anterior part of the neural tube which is the holoprosenchepaly (Brown et al., 1998). In mouse except holoprosencephaly Zic2 has been related also with spina bifida (Elms et al., 2003; Nagai et al., 2000). This discrepancy was though to come due to the lower levels of Zic2 in mutant mouse compare to Zic2 mutation in humans (Nagai et al., 2000). In human and mice has also been proved a dose sensitivity in Zic2 pathogenesis (Brown et al., 2001, 1998). However, a frequent polymorphism study exclude Zic2 as a risk factor for NDTs in humans (Klootwijk et al., 2004). This could indicate that
Zic2 function is less conserved in humans compare to mouse and it loss the determinant role for NTDs in the posterior part of the neural tube. Environmental factors which are not well addressed in mouse plays an important role in producing NTDs in human (Edison and Muenke, 2003; Liao et al., 2009). In humans related to the environmental factors are the regions where people live, in different region the incidence of NTDs was different (Chen et al., 2009). These entire factors probably make the difference in NTDs provoked by Zic2 in humans and mice.

During the time of neurulation, Zic2 is coexpressed with other members of Zic family. 
This implies to a possible redundancy effect of these genes with Zic2 during the process of neural tube formation. Zic1 and Zic3 are coexpressed with Zic2 in dorsal part of the neural tube (Nagai et al., 1997). The redundancy was seen between Zic1 and Zic2 in cerebellum development (Aruga et al., 2002) and between Zic3 and Zic2 during formation of mesoderm derivatives tissue (Inoue et al., 2007). These results indicate for a possible redundant of these genes and Zic2 during neural tube development. Zic5 is another gene which has a similar expression with Zic2 during the neural tube development (Nakata et al., 2000), in genome it has a near localization with Zic2 and has been described to provoke NTDs (Inoue et al., 2004). These results also make it a strong candidate to have a redundancy effect with Zic2 during the neural tube development.

The role of Zic2 in neural crest development.

The neural crest starts to appear during gastrulation in the border of neural and nonneural ectoderm and has the peak of development during neurulation and short after neural tube closure (Le Douarin and Kalcheim, 1999). Do to the expression of Zic2 on the area where neural crest develops, it has attracted the focus of biologist whose have seen it as a potential key factor during neural crest development. The expression of Zic2 during neural crest is described in migratory area and migrating neural crest cells (Elms et al., 2003; Nagai et al., 1997). However, there is not clear how is related Zic2 expression level with premigratory and migratory neural crest or with the specific migratory paths during neural crest migration, which will be interesting to focus in future studies.

Experiments in mouse Zic2ku/ku mutant demonstrated a delay and a reduction in neural crest, these changes that did not produce changes in cell death or proliferation (Elms et al., 2003). In Zic2 kd/kd mutant also was observed on impairment of neural crest (Nagai et al., 2000). In coherence with experiments in mouse, in zebrafish, the overexpression of Zic2a and
Zic2b increase neural crest production, that was manifested with upregulation levels of Sox10, a migrating neural crest maker (TeSlaa et al., 2013). In Xenopus, Zic2 overexpression also induces neural crest formation (Brewster et al., 1998; Nakata et al., 1998).

The neural crest cell after migrate to their final destination will differentiate in two type of cells; sensory neurons and melanocyte cells (Le Douarin and Kalcheim, 1999). There are no specific data about the mechanisms that Zic2 affects neural crest cells final fate. In Zic2 ${ }^{\text {kd/kd }}$ mutant was observed an impairment of sensory neurons which was manifested with a reduction of the dorsal root ganglia (Nagai et al., 2000). In the Zic2 ${ }^{\mathrm{ku} / k u}$ mutant were mentioned problems with pigmentation, manifested with white skin spots (Elms et al., 2003). These results are in coherence with studies in Xenopus where Zic2 overexpression produced ectopic melanocyte cells (Nakata et al., 1998) and in zebrafish where Zic2a and Zicb downregulation reduce the levels of melanocyte cells (TeSlaa et al., 2013).

In Xenopus the results related with neural crest derivatives are contradictory. The results form (Nakata et al., 1998) claimed that Zic2 overexpression induce neurogenesis whereas the study of (Brewster et al., 1998) claimed that Zic2 overexpression does not induce neurogenesis, it reduces neural tissue and maintains cells in a undifferentiated stage. This could have come due to different markers and experimental condition. Meanwhile, remains ambiguous with which cell fate Zic2 is related more. Does it induce more one or the other cell type? To answer this question are needed experiment with specific markers of these cells population during overexpression.

During neural crest development could also be present the redundancy effect of other Zic family members. Possible candidates to have a redundancy effect is Zic1, the overexpression of who induces neural crest expansion (Nagai et al., 1997; Sato et al., 2005). Zic3 is another gene that has been related with neural crest 
production (Life and Project, 1997; Nagai et al., 1997). Another strong candidate to have a redundancy effect with Zic2 is Zic5 which has been demonstrated to participate in neural crest development (Inoue et al., 2004; Nakata et al., 2000).

\section{Zic2 new target genes during neural tube and neural crest development.}

Some of the ephrin receptors are possible candidates to be related with Zic2 during neural tube formation. One of the candidates is EphA4 which have a similarity in the expression with Zic2 at the apical part of the neural tube (Abdullah et al., 2017; Santiago and Erickson, 2002) and has been involved in spina bifida (Abdullah et al., 2017). It was also demonstrated that Zic2 binds to EphA4 enhancer in embryonic stem cells (Luo et al., 2015). At the same time, it has been seen that Zic2 controls the expression of EphA4 in defining the ipsilateral projection of spinal cord interneurons (Escalante et al., 2013).

EphB1 is another ephrin receptor with a plausible relation with Zic2 during the neural tube formation, EphB1 has a similar expression with Zic2 in the dorsal part of the neural tube (Saeger et al., 2011; Santiago and Erickson, 2002). EphB1 has been demonstrated to participate in cell patterning and cell differentiation of the ventral part of the neural tube (Laussu et al., 2017). It also has been demonstrated that Zic2 control the expression of EphB1 in defining the ipsilateral projection in visuals system (García-Frigola et al., 2008; Lee et al., 2008). The same relationship is suggested to control cell migration of specific neurons during forebrain formation (Murillo et al., 2015). Altogether, these results indicate for a possible interaction between Zic2, EphA4 and EphB1 receptors during the formation of the neural tube. To further understanding these relations are needed other experiments as it could be to check for the levels of these receptors in the Zic2 mutant mouse or to study combined mutants between Zic2 and EphA4, EphB1 receptors. Nevertheless, as it was described in visual system and spinal cord where Zic2 operate with different ephrin receptors, adding the fact that other ephrin receptors expressed in an overlap pattern during the neural tube development (Abdul-Aziz et al., 2009). These evidences do not exclude that except EphB1 and EphA4 other ephrin receptors could be under the control of Zic2 during the neural tube development.

EphB1 and EphA4 also have been involved in neural crest development (Smith et al., 1997). This would need further exploration to see if the expression of these ephrin receptors is related with Zic2 during development of neural crest.

Noggin also has been related with neural tube dorsoventral patterning (McMahon et al., 1998). It is expressed in the dorsal part of the neural tube (Sela-Donenfeld and Kalcheim, 2000) and was shown to be controlled by Zic2 during neural plate bending (Nyholm et al., 2009). These indicate for a possible involvement of Zic2 and Noggin also in neural tube dorsoventral patterning, except the bending process.

New gene sequencing technologies like ChIPseq assessments has opened new paths for other gene candidates, which can interact with Zic2 during neural tube and neural crest development. Otx2 is a gene which expressed during forebrain development ( $\mathrm{Li}$ and Joyner), from the last study of ChIP-seq assessment was seen to interact with Zic2 (Matsuda et al., 2017). It would be interesting to explore the interaction of Otx2 and Zic2 during the neural tube development.

Fgf5 is a gene involved in ectoderm and neural differentiation (McGeachie et al., 2001; Wilson et al., 2001). It is expressed in a narrow area in the hindbrain region (Kumar and Chapman, 2012). Cheep-Seq assessment has demonstrated that Zic2 binds to Fgf5 enhancer (Luo et al., 2015; Matsuda et al., 2017). Further work is needed to see if Zic2 has direct influence in Fgf5 expression during the neural tube development or are implicated other intermediate factors.

It has been demonstrated that Zic2 also binds to Pou5f1 gene region (Luo et al., 2015). Pou5f1 is a gene which marks neural crest cells in a 
progenitor stage (Thomas et al., 2008). Zic2 could regulate PouF1 in premigratory neural crest cell, although other experiments are needed to see what happens with this interaction once neural crest cells migrate.

One of the signalling paths that has been involved in neural crest induction and migration is Wnt signalling (Burstyn-Cohen, 2004; Hari et al., 2002), that has been shown to be downstream Zic2. In vitro experiments on human cell demonstrated that Zic2 inhibit canonical Wnt signalling (Pourebrahim et al., 2011). This study is in coherence with the results found on the Wnt1 mutant mouse, which did not have changes in Zic2 levels (Nagai et al., 1997). However, in zebrafish has been described that Zic2a act downstream of Wnt canonical path (Nyholm et al., 2007). This could lead to a possible positive feedback loop between Zic2 and Wnt signalling which would need further investigations.

\section{Conclusions}

During the neural tube development, the results obtained until now showed that Zic2 is involved in bending process affecting DLHP through controlling Bmp2 antagonist and actin-myosin cytoskeletal elements. Other studies demonstrated an influence of Zic2 in neural tube patterning centres. In the ventral part, Zic2 affects Node signalling where it uses Tgif1 as effector gene. Zic2 has also an indirect relation with Shh signalling, where it controls Gli3 gene through Tgif1. Retinoid signalling is also another path which affected by Zic2. In this path, Zic2 uses Tgif1, Erf and Etv3 as effectors. In the dorsal part was seen that Zic2 produce a delay in roof plate formation. Related to cell differentiation during neural tube development was seen that Zic2 induce neural cells to remain in a progenitor stage. Remain to clarify the specific role of Zic2 on cell proliferation of each specific cell group that populate the apical part of the neural tube during this period.

During neural crest development, was seen that Zic2 affect neural crest production. It also affects neural crest derivatives, as it was melanocytes cells and sensory neurons. However, remain uncertainties related to the specific effect of Zic2 with each these neural crest derivatives. It is also not clear what is the expression of Zic2 on neural crest migratory paths

Chip-seq assessment has unveiled plausible new Zic2 target genes during the development of these structures. The ephrin receptors; EphB1 and EphA4 are possible targets of Zic2 during neural tube and neural crest development. Other genes are Fgf5, Otx2 and Pou5f1 are also a genes that could be related with Zic2 during neural tube development.

\section{Acknowledgements}

I want to thank El Consejo Superior de Investigaciones Científicas (CSIC) and Ministry of Science, Innovation and Universities of Spain for giving a fellowship to continue my $\mathrm{PhD}$ thesis.

A special thank is for Insituto de Neurociencias, Universidad Miguel Hernandez for offering work facilities and Dr. Eloisa Herrera for directing my $\mathrm{PhD}$ thesis.

Thank also to my actual working place: Agricultural University of Tirana and The Faculty of Veterinary Medicine for supporting during the time I was writing this review.

\section{References}

1. Abdul-Aziz, N.M., Turmaine, M., Greene, N.D.E., and Copp, A.J. (2009). EphrinA-EphA receptor interactions in mouse spinal neurulation: Implications for neural fold fusion. Int. J. Dev. Biol. 53, 559-568.

2. Abdullah, N.L., Mohd-Zin, S.W., Ahmad-Annuar, A., and Abdul-Aziz, N.M. (2017). A Novel OccultaType Spina Bifida Mediated by Murine Double Heterozygotes EphA2 and EphA4 Receptor Tyrosine Kinases. Front. Cell Dev. Biol. 5.

3. Ali, R.G., Bellchambers, H.M., and Arkell, R.M. (2012). Zinc fingers of the cerebellum (Zic): Transcription factors and co-factors. Int. J. Biochem. Cell Biol. 44, 2065-2068.

4. Alles, A.J., and Sulik, K.K. (1990). Retinoic acidinduced spina bifida: evidence for a pathogenetic mechanism. Dev. Camb. Engl. 108, 73-81.

5. Aruga, J., Nagai, T., Tokuyama, T., Hayashizaki, Y., Okazaki, Y., Chapman, V.M., and Mikoshiba, K. (1996). The Mouse Zic Gene Family: HOMOLOGUES OF THE DROSOPHILA PAIR- 
RULE GENE odd-paired. J. Biol. Chem. 271, 1043-1047.

6. Aruga, J., Inoue, T., Hoshino, J., and Mikoshiba, K. (2002). Zic2 controls cerebellar development in cooperation with Zic1. J. Neurosci. Off. J. Soc. Neurosci. 22, 218-225.

7. Bartholin, L., Powers, S.E., Melhuish, T.A., Lasse, S., Weinstein, M., and Wotton, D. (2006). TGIF Inhibits Retinoid Signaling. Mol. Cell. Biol. 26, 990-1001.

8. Brewster, R., Lee, J., and Ruiz i Altaba, a (1998). Gli/Zic factors pattern the neural plate by defining domains of cell differentiation. Nature 393, 579583.

9. Briscoe, J., Pierani, A., Jessell, T.M., and Ericson, J. (2000). A homeodomain protein code specifies progenitor cell identity and neuronal fate in the ventral neural tube. Cell 101, 435-445.

10. Brown, L.Y., Odent, S., David, V., Blayau, M., Dubourg, C., Apacik, C., Delgado, M.A., Hall, B.D., Reynolds, J.F., Sommer, A., et al. (2001). Holoprosencephaly due to mutations in ZIC2: alanine tract expansion mutations may be caused by parental somatic recombination. Hum. Mol. Genet. 10, 791-796.

11. Brown, S.A., Warburton, D., Brown, L.Y., Yu, C., Roeder, E.R., Stengel-rutkowski, S., Hennekam, R.C.M., and Muenke, M. (1998). Holoprosencephaly due to mutations in $\mathrm{ZIC2}$, a homologue of Drosophila odd-paired. 20, 3-6.

12. Burstyn-Cohen, T. (2004). Canonical Wnt activity regulates trunk neural crest delamination linking $\mathrm{BMP} /$ noggin signaling with $\mathrm{G} 1 / \mathrm{S}$ transition. Development 131, 5327-5339.

13. Chen, G., Pei, L.-J., Huang, J., Song, X.-M., Lin, L.-M., Gu, X., Wu, J.-X., Wang, F., Wu, J.-L., Chen, J.-P., et al. (2009). Unusual Patterns of Neural Tube Defects in a High Risk Region of Northern China. Biomed. Environ. Sci. 22, 340344.

14. Chiang, C., Litingtung, Y., Lee, E., Young, K.E., Corden, J.L., Westphal, H., and Beachy, P. a (1996). Cyclopia and defective axial patterning in mice lacking Sonic hedgehog gene function. Nature 383, 407-413.

15. Cohen, M.M., and Shiota, K. (2002). Teratogenesis of holoprosencephaly. Am. J. Med. Genet. 109, 1-15.

16. Copp, A.J., and Greene, N.D.E. (2013). Neural tube defects-disorders of neurulation and related embryonic processes. Wiley Interdiscip. Rev. Dev. Biol. 2, 213-227.
17. Copp, A.J., Greene, N.D.E., and Murdoch, J.N. (2003). The genetic basis of mammalian neurulation. Nat. Rev. Genet.

18. Drummond, D.L., Cheng, C.S., Selland, L.G., Hocking, J.C., Prichard, L.B., and Waskiewicz, A.J. (2013). The role of Zic transcription factors in regulating hindbrain retinoic acid signaling. BMC Dev. Biol. 13, 31-31.

19. Edison, R., and Muenke, M. (2003). The interplay of genetic and environmental factors in craniofacial morphogenesis: holoprosencephaly and the role of cholesterol. Congenit. Anom. 43, $1-21$.

20. Elms, P., Siggers, P., Napper, D., Greenfield, A., and Arkell, R. (2003). Zic2 is required for neural crest formation and hindbrain patterning during mouse development. Dev. Biol. 264, 391-406.

21. Elms, P., Scurry, A., Davies, J., Willoughby, C., Hacker, T., Bogani, D., and Arkell, R. (2004). Overlapping and distinct expression domains of Zic2 and Zic3 during mouse gastrulation. Gene Expr. Patterns 4, 505-511.

22. Escalante, A., Murillo, B., Morenilla-Palao, C., Klar, A., and Herrera, E. (2013). Zic2-dependent axon midline avoidance controls the formation of major ipsilateral tracts in the CNS. Neuron 80 , 1392-1406.

23. Franco, P.G., Paganelli, A.R., López, S.L., and Carrasco, A.E. (1999). Functional association of retinoic acid and hedgehog signaling in Xenopus primary neurogenesis. Dev. Camb. Engl. 126, 4257-4265.

24. Furushima, K., Murata, T., Matsuo, I., and Aizawa, S. (2000). A new murine zinc finger gene, Opr. Mech. Dev. 98, 161-164.

25. Galea, G.L., Cho, Y.-J., Galea, G., Molè, M.A., Rolo, A., Savery, D., Moulding, D., Culshaw, L.H., Nikolopoulou, E., Greene, N.D.E., et al. (2017). Biomechanical coupling facilitates spinal neural tube closure in mouse embryos. Proc. Natl. Acad. Sci. 201700934.

26. García-Frigola, C., Carreres, M.I., Vegar, C., Mason, C., and Herrera, E. (2008). Zic2 promotes axonal divergence at the optic chiasm midline by EphB1-dependent and -independent mechanisms. Dev. Camb. Engl. 135, 1833-1841.

27. Grinberg, I., and Millen, K.J. (2005). The ZIC gene family in development and disease. Clin. Genet. 67, 290-296.

28. Gripp, K.W., Wotton, D., Edwards, M.C., Roessler, E., Ades, L., Meinecke, P., RichieriCosta, A., Zackai, E.H., Massagué, J., Muenke, M., et al. (2000). Mutations in TGIF cause 
holoprosencephaly and link NODAL signalling to human neural axis determination. Nat. Genet. 25, 205-208.

29. Hari, L., Brault, V., Kléber, M., Lee, H.Y., Ille, F., Leimeroth, R., Paratore, C., Suter, U., Kemler, R., and Sommer, L. (2002). Lineage-specific requirements of $\beta$-catenin in neural crest development. J. Cell Biol.

30. Helms, A.W., and Johnson, J.E. (2003). Specification of dorsal spinal cord interneurons. Curr. Opin. Neurobiol. 13, 42-49.

31. Herrera, E., Brown, L., Aruga, J., Rachel, R. a, Dolen, G., Mikoshiba, K., Brown, S., and Mason, C. a (2003). Zic2 patterns binocular vision by specifying the uncrossed retinal projection. Cell 114, 545-557.

32. Houtmeyers, R., Souopgui, J., Tejpar, S., and Arkell, R. (2013). The ZIC gene family encodes multi-functional proteins essential for patterning and morphogenesis. Cell. Mol. Life Sci. CMLS.

33. Houtmeyers, R., Tchouate Gainkam, O., Glanville-Jones, H.A., Van den Bosch, B., Chappell, A., Barratt, K.S., Souopgui, J., Tejpar, S., and Arkell, R.M. (2016). Zic2 mutation causes holoprosencephaly via disruption of NODAL signalling. Hum. Mol. Genet. 25, 3946-3959.

34. Inoue, T., Hatayama, M., Tohmonda, T., Itohara, S., Aruga, J., and Mikoshiba, K. (2004). Mouse Zic5 deficiency results in neural tube defects and hypoplasia of cephalic neural crest derivatives. Dev. Biol. 270, 146-162.

35. Inoue, T., Ota, M., Mikoshiba, K., and Aruga, J. (2007). Zic2 and Zic3 synergistically control neurulation and segmentation of paraxial mesoderm in mouse embryo. Dev. Biol. 306, 669684.

36. Ishiguro, A., Hatayama, M., Otsuka, M.I., and Aruga, J. (2018). Link between the causative genes of holoprosencephaly: Zic2 directly regulates Tgif1 expression. Sci. Rep. 8.

37. Janesick, A., Abbey, R., Chung, C., Liu, S., Taketani, M., and Blumberg, B. (2013). ERF and ETV3L are retinoic acid-inducible repressors required for primary neurogenesis. Development 140, 3095-3106.

38. Kalcheim, C. (2018). Neural crest emigration: From start to stop. Genesis 56, e23090.

39. Klootwijk, R., Groenen, P., Schijvenaars, M., Hol, F., Hamel, B., Straatman, H., SteegersTheunissen, R., Mariman, E., and Franke, B. (2004). Genetic variants inZIC1,ZIC2, andZIC3 are not major risk factors for neural tube defects in humans. Am. J. Med. Genet. 124A, 40-47.
40. Koyabu, Y., Nakata, K., Mizugishi, K., Aruga, J., and Mikoshiba, K. (2001). Physical and Functional Interactions between Zic and Gli Proteins. J. Biol. Chem. 276, 6889-6892.

41. Kumar, M., and Chapman, S.C. (2012). Cloning and expression analysis of Fgf5, 6 and 7 during early chick development. Gene Expr. Patterns 12, 245-253.

42. Laussu, J., Audouard, C., Kischel, A., AssisNascimento, P., Escalas, N., Liebl, D.J., Soula, C., and Davy, A. (2017). Eph/Ephrin Signaling Controls Progenitor Identities In The Ventral Spinal Cord. Neural Develop. 12.

43. Le Douarin, N.M., and Kalcheim, C. (1999). The Neural Crest.

44. Lee, K.J., Mendelsohn, M., and Jessell, T.M. (1998). Neuronal patterning by BMPs: a requirement for GDF7 in the generation of a discrete class of commissural interneurons in the mouse spinal cord. Genes Dev. 12, 3394-3407.

45. Lee, R., Petros, T.J., and Mason, C.A. (2008). Zic2 Regulates Retinal Ganglion Cell Axon Avoidance of ephrinB2 through Inducing Expression of the Guidance Receptor EphB1. J. Neurosci. 28, 5910-5919.

46. Li, J.Y.H., and Joyner, A.L. Otx2 and Gbx2 in midhindbrain patterning. 13.

47. Liao, Y., Wang, J., Li, X., Guo, Y., and Zheng, X. (2009). Identifying environmental risk factors for human neural tube defects before and after folic acid supplementation. BMC Public Health 9.

48. Life, T., and Project, C.N. (1997). Xenopus Zic 3 , a primary regulator both in neural and neural. 94, 11980-11985.

49. Lu, S.-X., Zhang, C.Z., Luo, R.-Z., Wang, C.-H., Liu, L.-L., Fu, J., Zhang, L., Wang, H., Xie, D., and Yun, J.-P. (2017). Zic2 promotes tumor growth and metastasis via PAK4 in hepatocellular carcinoma. Cancer Lett. 402, 71-80.

50. Luo, Z., Gao, X., Lin, C., Smith, E.R., Marshall, S.A., Swanson, S.K., Florens, L., Washburn, M.P., and Shilatifard, A. (2015). Zic2 is an enhancer-binding factor required for embryonic stem cell specification. Mol. Cell 57, 685-694.

51. Maden, M. (2006). Retinoids and spinal cord development. J. Neurobiol. 66, 726-738.

52. Matsuda, K., Mikami, T., Oki, S., lida, H., Andrabi, M., Boss, J.M., Yamaguchi, K., Shigenobu, S., and Kondoh, H. (2017). ChIP-seq analysis of genomic binding regions of five major transcription factors highlights a central role for ZIC2 in the mouse epiblast stem cell gene 
regulatory network. Development 144, 19481958.

53. McGeachie, A.B., Koishi, K., Imamura, T., McLennan, I.S., and Department of Anatomy and Structural Biology, University of Otago, Dunedin, New Zealand (2001). Fibroblast growth factor-5 is expressed in Schwann cells and is not essential for motoneurone survival. Neuroscience 104, 891-899.

54. McMahon, A.R., and Merzdorf, C.S. (2010). Expression of the zic1, zic2, zic3, and zic4 genes in early chick embryos. BMC Res. Notes.

55. McMahon, J.A., Takada, S., Zimmerman, L.B., Fan, C.-M., Harland, R.M., and McMahon, A.P. (1998). Noggin-mediated antagonism of BMP signaling is required for growth and patterning of the neural tube and somite. Genes Dev. 12, 1438-1452.

56. Melloy, P.., Ewart, J.., Cohen, M.., Desmond, M.., Kuehn, M.., and Lo, C.. (1998). No turning,a Mouse Mutation Causing Left-Right and Axial Patterning Defects. Dev. Biol. 193, 77-89.

57. Murillo, B., Ruiz-Reig, N., Herrera, M., Fairen, a., and Herrera, E. (2015). Zic2 Controls the Migration of Specific Neuronal Populations in the Developing Forebrain. J. Neurosci. 35, 1126611280.

58. Nagai, T., Aruga, J., Takada, S., Gu, T., Spo, R., Schughart, K., and Mikoshiba, K. (1997). Gene Suggests an Essential Role for Zic Genes in Body Pattern Formation. 313, 299-313.

59. Nagai, T., Aruga, J., Minowa, O., Sugimoto, T., Ohno, Y., Noda, T., and Mikoshiba, K. (2000). Zic2 regulates the kinetics of neurulation. In Proceedings of the National Academy of Sciences of the United States of America, pp. 1618-1623.

60. Nakata, K., Nagai, T., Aruga, J., and Mikoshiba, K. (1998). Xenopus Zic family and its role in neural and neural crest development.

61. Nakata, K., Koyabu, Y., Aruga, J., and Mikoshiba, K. (2000). A novel member of the Xenopus Zic family, Zic5, mediates neural crest development. Mech. Dev. 99, 83-91.

62. Niederreither, K., Vermot, J., Schuhbaur, B., Chambon, P., and Dollé, P. (2000). Retinoic acid synthesis and hindbrain patterning in the mouse embryo. Dev. Camb. Engl. 127, 75-85.

63. Nitzan, E., Avraham, O., Kahane, N., Ofek, S., Kumar, D., and Kalcheim, C. (2016). Dynamics of BMP and Hes1/Hairy1 signaling in the dorsal neural tube underlies the transition from neural crest to definitive roof plate. BMC Biol. 14.
64. Nyholm, M.K., Wu, S.-F., Dorsky, R.I., and Grinblat, Y. (2007). The zebrafish zic2a-zic5 gene pair acts downstream of canonical Wnt signaling to control cell proliferation in the developing tectum. Dev. Camb. Engl. 134, 735-746.

65. Nyholm, M.K., Abdelilah-Seyfried, S., and Grinblat, Y. (2009). A novel genetic mechanism regulates dorsolateral hinge-point formation during zebrafish cranial neurulation. J. Cell Sci. 122, 2137-2148.

66. Pourebrahim, R., Houtmeyers, R., Ghogomu, S., Janssens, S., Thelie, A., Tran, H.T., Langenberg, T., Vleminckx, K., Bellefroid, E., Cassiman, J.J., et al. (2011). Transcription factor Zic2 inhibits Wnt/??-catenin protein signaling. J. Biol. Chem. 286, 37732-37740.

67. Saeger, B.M., Suhm, M., and Neubu, A. (2011). Ephrin / ephrin Receptor Expression During Early Stages of Mouse Inner Ear Development.

68. Sanek, N.A., and Grinblat, Y. (2008). A novel role for zebrafish zic2a during forebrain development. Dev. Biol. 317, 325-335.

69. Santiago, A., and Erickson, C.A. (2002). Ephrin-B ligands play a dual role in the control of neural crest cell migration. Development 129, 36213632.

70. Sato, T., Sasai, N., and Sasai, Y. (2005). Neural crest determination by co-activation of Pax3 and Zic1 genes in Xenopus ectoderm. Development 132, 2355-2363.

71. Sela-Donenfeld, D., and Kalcheim, C. (2000). Inhibition of noggin expression in the dorsal neural tube by somitogenesis: a mechanism for coordinating the timing of neural crest emigration. Dev. Camb. Engl. 127, 4845-4854.

72. Smith, a, Robinson, V., Patel, K., and Wilkinson, D.G. (1997). The EphA4 and EphB1 receptor tyrosine kinases and ephrin-B2 ligand regulate targeted migration of branchial neural crest cells. Curr. Biol. CB 7, 561-570.

73. Taniguchi, K., Anderson, A.E., Sutherland, A.E., and Wotton, D. (2012). of Tgif Function Causes HoloprosenceLoss phaly by Disrupting the Shh Signaling Pathway. PLoS Genet. 8, e1002524.

74. Taniguchi, K., Anderson, A.E., Melhuish, T.A., Carlton, A.L., Manukyan, A., Sutherland, A.E., and Wotton, D. (2017). Genetic and Molecular Analyses indicate independent effects of TGIFs on Nodal and Gli3 in neural tube patterning. Eur. J. Hum. Genet. 25, 208-215.

75. TeSlaa, J.J., Keller, A.N., Nyholm, M.K., and Grinblat, Y. (2013). Zebrafish Zic2a and Zic2b 
regulate neural crest and craniofacial development. Dev. Biol. 380, 73-86.

76. Thomas, A.J., and Erickson, C. a (2009). FOXD3 regulates the lineage switch between neural crestderived glial cells and pigment cells by repressing MITF through a non-canonical mechanism. Dev. Camb. Engl. 136, 1849-1858.

77. Thomas, S., Thomas, M., Wincker, P., Babarit, C., Xu, P., Speer, M.C., Munnich, A., Lyonnet, S., Vekemans, M., and Etchevers, H.C. (2008). Human neural crest cells display molecular and phenotypic hallmarks of stem cells. Hum. Mol. Genet. 17, 3411-3425.

78. Warr, N., Powles-Glover, N., Chappell, A., Robson, J., Norris, D., and Arkell, R.M. (2008). Zic2-associated holoprosencephaly is caused by a transient defect in the organizer region during gastrulation. Hum. Mol. Genet. 17, 2986-2996.

79. Wilson, L., Gale, E., Chambers, D., and Maden, M. (2004). Retinoic acid and the control of dorsoventral patterning in the avian spinal cord. Dev. Biol. 269, 433-446.

80. Wilson, S., Rydström, A., Trimborn, T., Willert, K., Nusse, R., Jessell, T.M., and Edlund, T. (2001). The status of Wnt signalling regulates neural and epidermal fates in the chick embryo. Nature 411, 325-330.

81. Wotton, D., Lo, R.S., Lee, S., and Massagué, J. (1999). A Smad Transcriptional Corepressor. Cell 97, 29-39.

82. Ybot-Gonzalez, P., Cogram, P., Gerrelli, D., and Copp, A.J. (2002). Sonic hedgehog and the molecular regulation of mouse neural tube closure. Dev. Camb. Engl. 129, 2507-2517.

83. Ybot-Gonzalez, P., Gaston-Massuet, C., Girdler, G., Klingensmith, J., Arkell, R., Greene, N.D.E., and Copp, A.J. (2007). Neural plate morphogenesis during mouse neurulation is regulated by antagonism of $\mathrm{Bmp}$ signalling. Development 134, 3203-3211.

84. Zohn, I.E., and Sarkar, A.A. (2008). Modeling neural tube defects in the mouse. Curr. Top. Dev. Biol. 84, 1-35. 